\title{
Erratum: Hůnová, I. Ambient Air Quality in the Czech Republic: Past and Present. Atmosphere 2020, 11, 214
}

\section{Iva Hůnová}

check for updates

Citation: Hůnová, I. Erratum: Hůnová, I. Ambient Air Quality in the Czech Republic: Past and Present. Atmosphere 2020, 11, 214. Atmosphere 2021, 12, 720. https://doi.org/ $10.3390 /$ atmos 12060720

Received: 29 April 2021 Accepted: 20 May 2021 Published: 4 June 2021

Publisher's Note: MDPI stays neutral with regard to jurisdictional claims in published maps and institutional affiliations.

\section{Copyright: (c) 2021 by the author.} Licensee MDPI, Basel, Switzerland. This article is an open access article distributed under the terms and conditions of the Creative Commons Attribution (CC BY) license (https:// creativecommons.org/licenses/by/ $4.0 /)$.
Ambient Air Quality Department, Czech Hydrometeorological Institute, Na Šabatce 17, 14306 Praha 4, Czech Republic; iva.hunova@chmi.cz

\section{Text Correction}

There was an error in the original article [1]. With 3150 kilotons in 1985, i.e., a full $203 \mathrm{~kg}$ per person per year in 1985, SO 2 emissions in the CR were the highest in Europe, 2.48 times higher than in Western Europe per unit of gross national product (GNP) [23].

A correction has been made to 2.1. Emission Sources and Source Areas, Paragraph 4:

With 3150 kilotons in 1985, i.e., a full $203 \mathrm{~kg}$ per person per year in 1985, SO 2 emissions in the Czech-Slovak Federal Republic (CSFR) were the highest in Europe, 2.48 times higher than in Western Europe per unit of gross national product (GNP) [23].

The author apologizes for any inconvenience caused and state that the scientific conclusions are unaffected. The original article has been updated.

Conflicts of Interest: The author declares no conflict of interest.

\section{Reference}

1. Hůnová, I. Ambient Air Quality in the Czech Republic: Past and Present. Atmosphere 2020, 11, 214. [CrossRef] 